\title{
Anti-inflammatory and proliferative responses in human and ovine ovarian surface epithelial cells
}

\author{
O Gubbay, W Guo, M T Rae, D Niven, A F Howie, A S McNeilly ${ }^{1}$, L X $\mathrm{u}^{2}$ and S G Hillier \\ Department of Reproductive and Developmental Sciences and ${ }^{1}$ Human Reproductive Sciences Unit, \\ Medical Research Council, Centre for Reproductive Biology, University of Edinburgh, The Chancellor's Building, \\ 49 Little France Crescent, Old Dalkeith Road, Edinburgh EH16 4SB, UK and ${ }^{2}$ FibroGen, Inc., 225 Gateway \\ Boulevard, South San Francisco, CA 94080, USA
}

Correspondence should be addressed to O Gubbay; Email: ogubby@staffmail.ed.ac.uk

\begin{abstract}
The majority of ovarian cancers ( $>90 \%)$ are believed to derive from the ovarian surface epithelium (OSE); a single layer covering the entire surface of the ovary. At ovulation, the OSE cell layer undergoes an inflammatory response, involving cell death and growth, in order to overcome ovarian surface rupture. Abnormalities during these processes are believed to contribute to the development of tumours. Using primary cultures of OSE cells, we have compared anti-inflammatory and proliferative responses directly between human and ovine OSE cells to further establish the use of ovine OSE cells as a suitable model system for the study of human OSE cells. In order to compare effects of inflammatory stimulation, expression and activity of $11 \beta$ hydroxysteroid dehydrogenase (11ßHSD) type 1 was measured in OSE cells in response to interleukin (IL)-1 $\alpha$. As previously identified in human OSE cells, treatment of ovine OSE cells with IL-1 $\alpha$ stimulated a concomitant increase of $11 \beta \mathrm{HSD}$ type $1 \mathrm{mRNA}(31$-fold; $P<0.05$ ) and oxoreductase activity, indicating an increased production of antiinflammatory cortisol. To compare the growth of human and ovine OSE cells, OSE cell number was measured in response to treatment with gonadotropins or growth factors. In the presence of FSH, LH or human chorionic gonadotropin (hCG), ovine and human OSE cell growth was similarly stimulated $>1.2$-fold $(P<0.05)$. In the presence of connective tissue growth factor (CTGF) and more significantly insulin growth factor I (IGF-I), human and ovine OSE cell growth was also similarly stimulated $>1.2$-fold $(P<0.05)$ and $>1.5$-fold $(P<0.01)$, respectively. The induction of both human and ovine OSE cell growth by IGF-I or hCG was further shown to be dependent on activation of the MAP kinase/extracellular-signal-regulated kinase (ERK) pathway. Stimulation of ovine OSE cell growth by hepatocyte growth factor (HGF) was similarly shown to be ERK-dependent; however, for human OSE cells, HGF only mildly stimulated ERK phosphorylation and failed to stimulate OSE cell growth. The demonstration that human and ovine OSE cells share similarities at the level of cell signalling, gene expression and cellular growth supports the use of ovine OSE cells as a suitable model for the study of human OSE cells.

Reproduction (2004) 128 607-614
\end{abstract}

\section{Introduction}

The majority of ovarian cancers are believed to derive from ovarian surface epithelial (OSE) cells that form the cuboidal epithelium around the ovary. The ovulatory process itself is thought to contribute to the aetiology of cancer based on the relationship between the number of ovulatory cycles and the incidence of cancer (Richardson et al. 1985, Piver et al. 1991). Immediately after rupture of a pre-ovulatory follicle, under control of gonadoptropins, the ovary undergoes extensive tissue remodelling involving cellular repair and growth. The processes that control such tissue remodelling are believed to be synonymous with mechanisms of inflammation (Espey 1980, 1994), and it is the persistence of genetic damage caused by inflammation that is proposed as a mechanism for the aetiology of ovarian epithelial cancers (Ness et al. 2000). Understanding the mechanisms of normal OSE cell growth and survival would therefore enable us to further delineate OSE dysfunction and tumour development.

Although studies have been performed on isolated human OSE cells in vitro (reviewed in Auersperg et al. 2001), due to the difficulty of obtaining OSE samples (or ovarian tissue) from suitable women and maintaining OSE cells in culture there is a need for a suitable animal model. Manipulation of such an animal model would also enable a more defined study of OSE cells with respect to oestrous-cycle stage. Our understanding of sheep reproductive physiology makes these monovulatory animals an obvious choice (Campbell et al. 2003). In this study we 
further previous reports (reviewed by Murdoch and McDonnel 2002) to demonstrate the use of ovine OSE cells as a suitable model system by comparing anti-inflammatory and proliferative responses directly between ovine and human OSE cells.

Exposure to inflammatory stimuli increases $11 \beta$ hydroxysteroid dehydrogenase type 1 (11ßHSD-1) expression and activity in various epithelial cell types (Escher et al. 1997, Feinstein and Schleimer 1999, Cai et al. 2001, Schleimer 1991). In the ovary, inflammatory stimuli induce $11 \beta$ HSD-1 expression and activity in granulosa cells (Tetsuka et al. 1999) and OSE cells (Yong et al. 2002). 11ßHSD-1 is predominantly an 11-oxoreductase that reversibly metabolizes cortisone to cortisol (Tannin et al. 1991, Stewart and Mason 1995), and the local increase of cortisol is believed to play a role in providing an anti-inflammatory environment to counteract inflammation caused at ovulation (Andersen and Hornnes 1994, Escher et al. 1997, Hillier and Tetsuka 1998, Yong et al. 2002, Rae et al. 2004). To ascertain a similar inflammatory response in ovine OSE cells, the mRNA level and oxoreductase activity of $11 \beta$ HSD-1 mRNA was measured in the present study.

In order to compare proliferative effects between human and ovine OSE cells, the growth of OSE cells was examined in response to gonadotropins and growth factors. The growth factors examined - connective tissue growth factor (CTGF), hepatocyte growth factor (HGF) and insulin-like growth factor I (IGF-I) - are implicated in diverse epithelial cell types as paracrine and autocrine regulators of mitosis and remodelling of the extracellular matrix and synthesized locally within the ovary under the control of gonadotropin stimulation. CTGF is expressed within OSE cells (Liu et al. 2002; C Harlow \& SG Hillier, unpublished observations) and granulosa cells under the control of gonadotropins (Slee et al. 2001, Liu et al. 2002). HGF is expressed in theca-interstitial and granulosa cells (Zachow and Woolery 2002) and shown to be up-regulated by follicle-stimulating hormone (FSH) and human chorionic gonadotropin (hCG; Parrott et al. 2001). Although IGF-I is also expressed in granulosa cells, the concentration of IGF-I in follicular fluid was shown not to significantly change across the estrous cycle (Leeuwenberg et al. 1996). However, IGF-I has been shown more recently to be up-regulated in response to hCG in human OSE cells (Kuroda et al. 2001).

The data presented here compare the induction of an anti-inflammatory response and cellular growth directly between primary cultures of human and ovine OSE cells. Treatment of ovine OSE cells with the inflammatory cytokine, interleukin (IL)- $1 \alpha$, stimulated a concomitant increase of $11 \beta \mathrm{HSD}-\mathrm{I}$ mRNA and oxoreductase activity (measured as conversion of cortisone to cortisol). By comparing the growth of human and ovine OSE cells, we conclude that both are stimulated similarly in response to gonadotropins and growth factors and identify the extracellular-signal-regulated kinase (ERK)/MAP kinase pathway as a necessary signalling pathway required for the induction of OSE cell growth by either IGF-I or hCG.
The similarities observed between human and ovine OSE cells therefore make ovine OSE cells suitable for the study of human OSE cells.

\section{Materials and Methods Isolation of OSE cells}

Human and ovine OSE cells were obtained by gentle scraping of the ovarian surface with a sterile wooden spatula, which was then rinsed into culture media consisting of M199/MCDB 105 medium containing 10\% foetal bovine serum (FBS), $100 \mathrm{U} / \mathrm{ml}$ penicillin and $100 \mu \mathrm{g} / \mathrm{ml}$ streptomycin (Sigma). In total, scrapings were taken of ovaries from 8 women and 10 sheep at different stages of the reproductive cycle. Human OSE cells were obtained (with informed consent after local ethical committee approval) from normal ovaries of premenopausal women undergoing non-pathological reproductive surgery. For human OSE cells, cells were collected as near to the beginning of surgical procedure as practicable to avoid any contamination with blood cells. OSE cells were then examined by phase-contrast microscopy to ensure that sufficient flakes of OSE had been obtained and cultured in donor calf serum-precoated flasks $\left(75 \mathrm{~cm}^{2}\right.$; Corning, Glass Works, Corning, NY, USA).

\section{Culture of OSE cells}

Human and ovine OSE cells were incubated in M199/MCDB 105 medium containing 10\% FBS, $100 \mathrm{U} / \mathrm{ml}$ penicillin and $100 \mu \mathrm{g} / \mathrm{ml}$ streptomycin (Sigma) at $37^{\circ} \mathrm{C}$ in a humidified incubator under an atmosphere of $95 \%$ air/5\% $\mathrm{CO}_{2}$ for up to 28 days, with media renewed every 7 days. Confluent cell monolayers were routinely obtained in 21 days using this system. Monolayers were examined routinely by phase-contrast microscopy for contaminating cells such as fibroblasts, and confirmation of cell purity was confirmed in selected cases with immunocytochemical staining for cytokeratins 5, 6, 8 and 17 (Auersperg et al. 2001) using a commercially available monoclonal anti(human cytokeratin) antibody (Dako, Glostrup, Denmark), which revealed that monolayers were pure epithelial cells using this culture system (results not shown). Confluent OSE monolayers were treated with trypsin-EDTA in Hanks balanced salt solution $(0.05 \%(\mathrm{w} / \mathrm{v})$ trypsin/0.5 mM EDTA; Invitrogen Life Technologies Ltd, Paisley, UK) at $37^{\circ} \mathrm{C}$ for $5 \mathrm{~min}$. Cells were then collected by centrifugation at $800 \mathrm{~g}>$ for $5 \mathrm{~min}$. The cell pellet was washed in culture media and resuspended in fresh media. Cell number and viability (>90\%) were determined by Trypan Blue (Sigma) exclusion and counting using a haemocytometer.

\section{Preparation of CTGF}

Recombinant human CTGF (rhCTGF) was produced in a baculovirus expression system using Hi5 cells adapted for suspension growth and virus containing a complete human CTGF cDNA. Cells were cultured in Sf 900 II SFM 
(Invitrogen Life Technologies Ltd, Paisley, UK) supplemented with $20 \mu \mathrm{g} / \mathrm{ml}$ gentamicin (CellGro, Hemdon, VA, USA) and $1 \mathrm{X}$ lipid (Life Technologies) and then scaled up for production in 3 I Fernbach culture flasks (Corning, Glass Works, Corning, NY, USA). When cultures reached a density of $(1.0-1.5) \times 10^{6}$ cell $\mathrm{s} / \mathrm{ml}$ with a viability of $>95 \%$, the cells were infected with human CTGF recombinant baculovirus at a multiplicity of infection of 10 . Conditioned media containing rhCTGF was harvested $40 \mathrm{~h}$ post-infection, centrifuged (10000 r.p.m., $10 \mathrm{~min}$ ), sterile filtered ( $0.45 \mu \mathrm{M}$ membrane) and then passed over a heparin-Sepharose affinity column (Amersham Pharmacia). The heparin column was washed with 10 column volumes of $350 \mathrm{mM} \mathrm{NaCl}$ and rhCTGF was eluted using a linear $\mathrm{NaCl}$ gradient $(350-1200 \mathrm{mM})$ for 15 column volumes, followed by step elution with five column volumes of $1200 \mathrm{mM} \mathrm{NaCl}$. rhCTGF was identified in eluted peak fractions by SDS/PAGE, and then fractions were pooled, diluted with Dd water until a conductivity of $5.7 \mathrm{mS}$ was reached, and the $\mathrm{pH}$ adjusted to 8.0. Although buffers, columns and plumbing were all sterilized, any residual endotoxin was removed by purification over Q-Sepharose/carboxymethyl polystyrene tandem columns. Under these conditions, endotoxin remained on the resin, while the rhCTGF first flowed through the Q-Sepharose (calculated $\mathrm{pl}$ of $\mathrm{CTGF}=8.37$ ) and then readily bound the carboxymethyl polystyrene resin. Final sample pools were assayed for total protein content and endotoxin. rhCTGF content and quality were evaluated by ELISA, SDS/PAGE and Western blot.

\section{Western blotting}

Human and ovine OSE cells were seeded in six-well plates (200000 cells/well) for $48 \mathrm{~h}$. The cells were then serum starved overnight before treatment. OSE cell monolayers were lysed in $150 \mathrm{mM} \mathrm{NaCl}, 10 \mathrm{mM}$ Tris (pH 7.4), $1 \mathrm{mM}$ EDTA, $10 \%$ glycerol, $1 \%$ Nonidet P40, $10 \mu \mathrm{g} / \mathrm{ml}$ aprotonin, $1 \mathrm{mM}$ PMSF and $1 \mathrm{mM}$ sodium orthovanadate. Cell extracts were prepared by centrifugation for $2 \mathrm{~min}$ at 14000 r.p.m. A total of $50 \mu \mathrm{g}$ protein was subjected to SDS/PAGE $(10 \%$ polyacrylamide gel) and then transferred to PVDF membrane (Millipore, Bedford, MA, USA). Membranes were incubated with antibodies against ERK 1/2 (Santa Cruz Biotechnology, Santa Cruz, CA, USA) or phosphorylated ERK 1/2 (Thr-202/Tyr-204; Cell Signaling, Beverly, MA, USA). Each antibody was diluted 1000 -fold in $2 \%$ dried skimmed milk/TBST $(20 \mathrm{mM}$ Tris/HCl, pH 7.4/500 mM NaCl/0.1\% Tween 20). Membranes were washed briefly in TBST and incubated with secondary antibodies conjugated to horseradish peroxidase (Amersham), in $2 \%$ milk/TBST. Membranes were again washed in TBST and proteins detected using the ECL + detection kit (Amersham).

\section{OSE cell-proliferation assay}

Human and sheep OSE cells were seeded in 96-well plates (5000 cells/well) and incubated with M199/MCDB
105 medium containing $10 \%$ FBS, $100 \mathrm{U} / \mathrm{ml}$ penicillin and $100 \mu \mathrm{g} / \mathrm{ml}$ streptomycin for $24 \mathrm{~h}$. The medium was replaced with serum-free medium and incubated for a further $24 \mathrm{~h}$. Treatments were then added to the cells for $72 \mathrm{~h}$. hCG was obtained from Sigma and recombinant human HGF purchased from PeproTech, Rocky Hill, NJ, USA. Recombinant human FSH and luteinizing hormone (LH) were donated by Dr C Howles (Serono Laboratories, Welwyn Garden City, Herts, UK) and recombinant human IGF-I by HH Peter and K Scheibli (Novartis, Basel, Switzerland). Where indicated, the MAP kinase/ERK kinase (MEK) inhibitor PD98059 (Calbiochem-Novabiochem, Nottingham, UK) was also added at a final concentration of $50 \mu \mathrm{M} 3 \mathrm{~h}$ prior to treatment and during the rest of the incubation. Cell growth was measured using the CellTiter 96 Aqueous One solution cell-proliferation assay according to the manufacturer's instructions (Promega).

\section{RNA extraction and quality analysis}

Human and ovine OSE cells were seeded in 12-well plates (50000 cells/well) and incubated for $48 \mathrm{~h}$. The cells were then serum starved overnight and treated with recombinant human $\mathrm{IL}-1 \alpha$ at $0.5 \mathrm{ng} / \mathrm{ml}$ (R\&D Systems Europe, Abingdon, Oxon, UK) for a further $48 \mathrm{~h}$. For each sample, RNA was extracted from six wells of OSE cells using RNeasy minispin columns (Qiagen, Crawley, West Sussex, UK) according to the manufacturer's instructions. One-microlitre aliquots of purified RNA were removed for quantification and quality assessment using the Agilent 2100 Bioanalyser system for total RNA in combination with RNA6000nano chips (Agilent Technologies, Stockport, Cheshire, UK). Only RNA which displayed intact $18 \mathrm{~S}$ and $28 \mathrm{~S}$ peaks was reverse transcribed to CDNA for PCR analysis, ensuring that downstream analyses were not skewed by degraded RNA and that equal amounts of RNA were reverse transcribed.

\section{Real-time PCR analysis}

Total RNA (1 $\mu \mathrm{g})$ was DNase treated ( $1 \mathrm{U}$; Invitrogen); $200 \mathrm{ng}$ of treated RNA was reverse transcribed in a final volume of $10 \mu \mathrm{l}$ (random hexamer kit; Applied Biosystems). Of this cDNA reaction, $2 \mu \mathrm{l}$ was added to a $25 \mu \mathrm{l}$ final volume containing $300 \mathrm{nM}$ primers, $200 \mathrm{nM}$ TaqMan hybridization probe and diluted PCR master mix (Biosource, Nivelles, Belgium). Primers and probes were designed using Primer-Express software (Perkin Elmer, Boston, MA, USA), spanning intron regions to avoid any contaminating genomic DNA amplification. For human $11 \beta \mathrm{HSD}-1$, the following primers were used: forward primer (5'-AAG ATG TTC CTG CAT GGA TTT C-3'), reverse primer (5'-AGC TCT GCG CCA AGA AGA AGT-3') and probe (5'-TGA CAG CTC ACT CTG GAC CAC TCT TCT GA-3'). For ovine $11 \beta \mathrm{HSD}-1$, the following primers were used: forward primer (5'-TTG CTC TGG ATG GGT TCT TCT C-3'), reverse primer (5'-CAG AGG GTG ATT GAC 
ACA TTG AC- $3^{\prime}$ ) and probe (5'-TCA GGA CGG AAT ATG AGG CGA CCA A-3'). Target mRNA was quantified in relation to $18 \mathrm{~S}$ rRNA abundance in each sample, with suitable positive control RNAs: human liver total RNA (Ambion, Huntingdon, Cambridgeshire, UK) and inhouse-prepared human placental mRNA. Negative controls included RT-negative (RNA template with no reverse transcriptase enzyme), $\mathrm{RT}-\mathrm{H}_{2} \mathrm{O}$ (water in place of RNA template) and cDNA-negative, where cDNA was replaced with water.

\section{1-Oxoreductase assay}

Interconversion of $\left[1,2,6,7_{-}{ }^{3} \mathrm{H}\right]$ cortisone and $\left[1,2,6,7_{-}{ }^{3} \mathrm{H}\right]$ cortisol was measured as the index of 11-oxoreductase activity, as described previously (Thomas et al. 1998) with the following alterations. OSE cells were seeded in 6-well plates (200000 cells/well) and incubated for $48 \mathrm{~h}$. Cells were serum starved overnight and incubated for a further $42 \mathrm{~h}$ in the presence of recombinant human IL-1 $\alpha$ at $0.5 \mathrm{ng} / \mathrm{ml}$ (R\&D Systems Europe, Abingdon, Oxon, UK). Culture medium containing either cortisol or cortisone $(50 \mathrm{pmol})$, including $0.1 \mu \mathrm{Ci}\left[{ }^{3} \mathrm{H}\right]$ cortisone or cortisol, was added to each well giving a final volume of $0.5 \mathrm{ml}$ and incubated for a further $4 \mathrm{~h}$. Control incubations containing no cells were also set up. Media from individual wells were then pipetted into glass tubes and vortexed with dichloromethane $(3 \mathrm{ml})$ for $1 \mathrm{~min}$ to extract steroids. The extracts were then evaporated under nitrogen in tubes containing $10 \mathrm{nmol}$ unlabelled cortisone and cortisol. The dried extracts were then dissolved in $100 \mu$ l dichloromethane and spotted on to silica-gel-precoated plastic sheets (PE SIL G; Whatman, Maidstone, Kent, UK) for thin-layer chromatographic separation of cortisone and cortisol, using a solvent system consisting of chlorofor$\mathrm{m} / \mathrm{ethanol}$ (92:8) as the mobile phase. The TLC plate was then scanned using a Bioscan 200 imaging detector (Lablogic Systems, Sheffield, UK).

\section{Statistical analysis}

Statistics were performed using SuperANNOVA followed by pairwise $t$ tests (Abacus Concepts, Berkeley, CA, USA).

\section{Results}

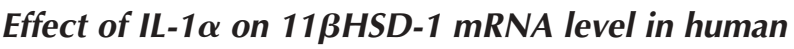 and ovine OSE cells}

Yong et al. (2002) observed previously that treatment of human OSE cells with IL- $1 \alpha$ induces an increase of $11 \beta \mathrm{HSD}-1 \mathrm{mRNA}$ level. In order to compare the effect of IL-1 $\alpha$ on $11 \beta \mathrm{HSD}-1$ mRNA level between human and ovine OSE cells, OSE cells were incubated in the presence or absence of $0.5 \mathrm{ng} / \mathrm{ml} \mathrm{IL}-1 \alpha$ for $48 \mathrm{~h}$ and $11 \beta \mathrm{HSD}-1$ mRNA analysed by real-time PCR (Fig. 1). Treatment of human OSE cells with IL-1 $\alpha$ was shown to induce 30 -fold increase $(P<0.001)$ of $11 \beta \mathrm{HSD}-1 \mathrm{mRNA}$, as previously documented (Yong et al. 2002). Treatment of ovine OSE

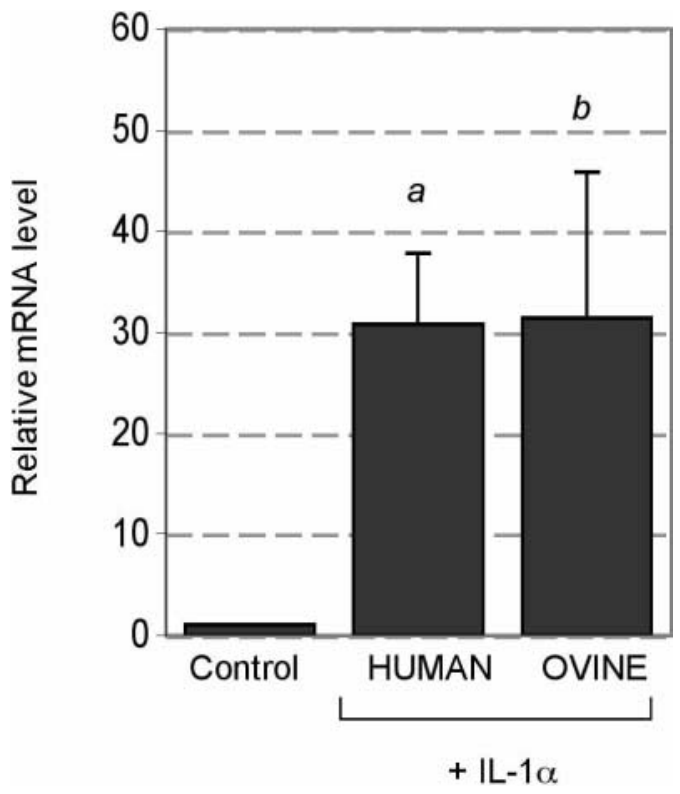

Figure 1 Effect of IL- $1 \alpha$ on $11 \beta$ HSD- 1 mRNA in human and ovine OSE cells. OSE cells were serum starved and incubated in the presence or absence of $0.5 \mathrm{ng} / \mathrm{ml} \mathrm{IL-1} \alpha$ for $48 \mathrm{~h}$. Real-time PCR was performed on cDNA prepared from cells using primers and probe specific to either ovine or human $11 \beta \mathrm{HSD}-1$ genes. Data $(n=3)$ were standardized to the control and are presented as fold increase and means \pm S.E.M. ( $a$ denotes $P<0.001$ and $b$ denotes $P<0.05$ ).

cells similarly induced a 31 -fold increase $(P<0.05)$ of $11 \beta$ HSD-1 mRNA.

\section{Effect of IL-1a on 11-oxoreductase activity in ovine OSE cells}

Based on a previous report that demonstrates maximal 11 -oxoreductase activity after $48 \mathrm{~h}$ treatment with IL-1 $\alpha$ in human OSE cells (Yong et al. 2002), ovine OSE cells were similarly treated with $\mathrm{IL}-1 \alpha$ for $48 \mathrm{~h}$ before measuring activity of 11-oxoreductase (Fig. 2). Ovine OSE cells were treated with and without IL-1 $\alpha$ in the presence of either cortisol or cortisone. In the presence of cortisol, no detectable cortisone was observed in the presence of $\mathrm{IL}-1 \alpha$, suggesting that little, if any, cortisol was converted to cortisone in the presence of IL-1 $\alpha$. However, in the presence of cortisone, an additional peak was observed in the presence of IL-1 $\alpha$ that corresponded to the presence of cortisol, suggesting that cortisone was converted to cortisol in the presence of IL- $1 \alpha$.

\section{Effect of growth factors on ovine and human OSE cell growth}

Cultured human and ovine OSE cells were seeded in 96-well plates and treated with varying concentrations of fetal calf serum (FCS), human gonadotropins (hCG, recombinant $\mathrm{LH}$ and recombinant $\mathrm{FSH}$ ) and human recombinant growth factors (CTGF, IGF-I and HGF) for $72 \mathrm{~h}$. Growth was determined using an assay that detects production of formazan from a tetrazolium salt (Fig. 3). 

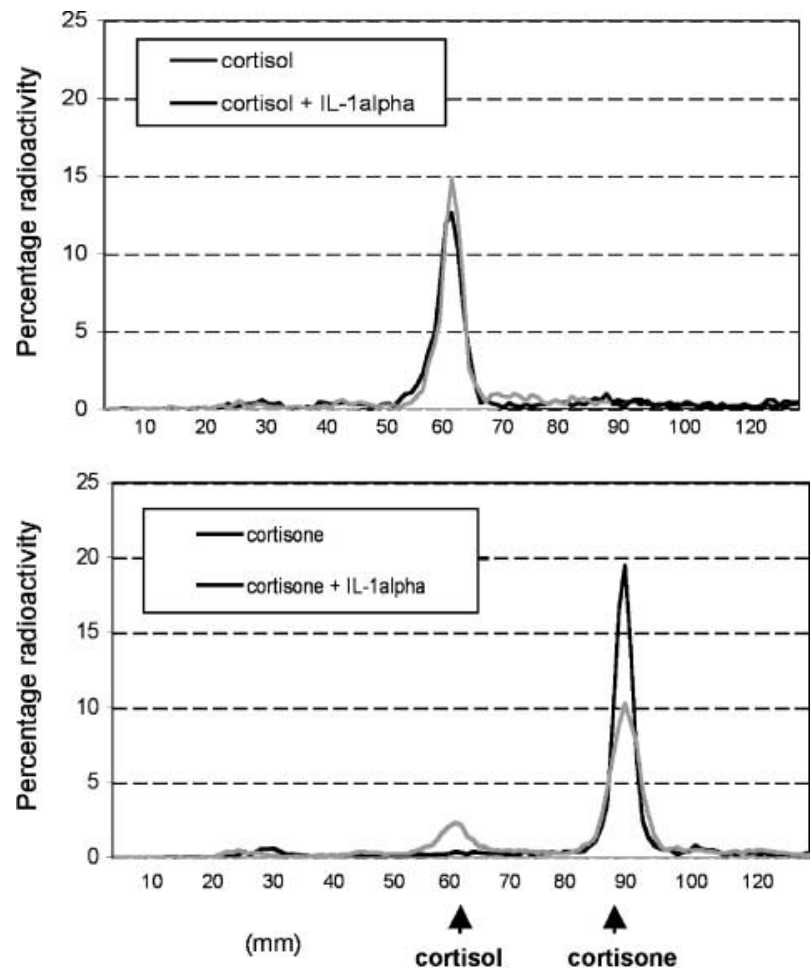

Figure 2 Effect of IL-1 $\alpha$ on 11-oxoreductase activity in ovine OSE cells. Ovine OSE cells were treated with and without IL- $1 \alpha$ for $48 \mathrm{~h}$ in the presence of cortisone or cortisol, as indicated. 11-oxoreductase activity was determined as described in the Materials and Methods section. One example of three experiments is presented.

(A)

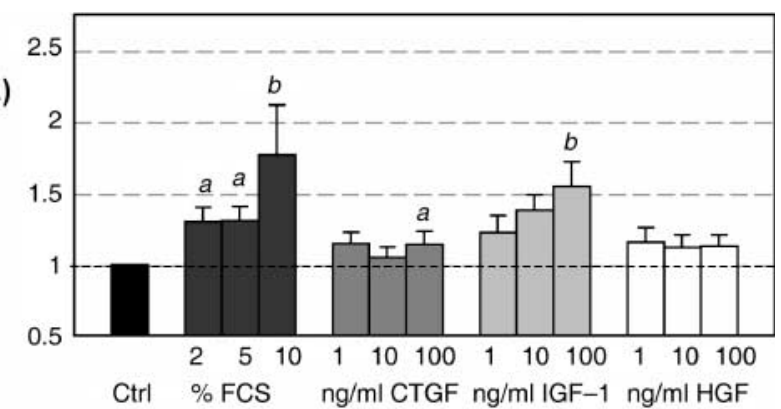

(B)

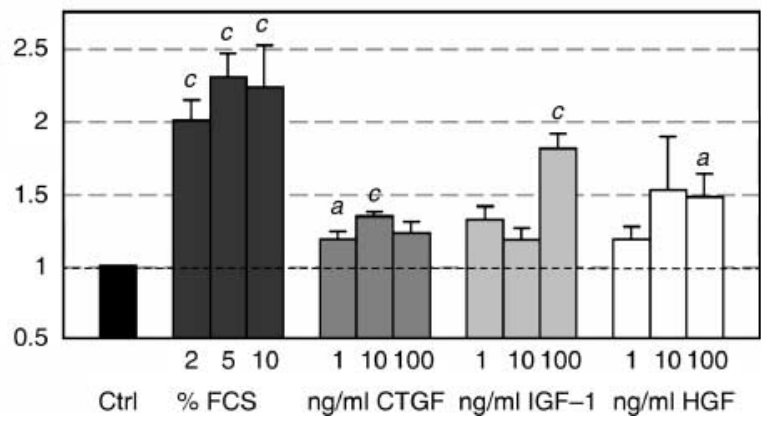

Figure 3 Effect of growth factors on (A) human and (B) ovine OSE cell growth. OSE cells were serum starved overnight and treated as indicated for 5 days. Cell number was ascertained using a tetrazoliumbased assay. Data $(n=6)$ were standardized to the control $(C t r l)$ and are presented as fold increase and means \pm S.E.M. (a denotes $P<0.05, b$ denotes $P<0.01$ and $c$ denotes $P<0.001$ ).
The addition of FCS to OSE cells more significantly induced ovine OSE cell growth compared with human OSE cell growth; at $10 \%$ FCS, human OSE cell growth was stimulated $>1.7$-fold $(P<0.01)$ and ovine OSE cell growth $>2.2$-fold $(P<0.001)$. When treated with growth factors, CTGF, and more significantly IGF-I, were shown to induce growth of both ovine and human OSE cells. The stimulation of growth in response to IGF-I was greatest in both human and ovine OSE cells at $100 \mathrm{ng} / \mathrm{ml}$, demonstrating $>1.5$-fold stimulation of cell growth $(P<0.01)$. Addition of CTGF, however, induced $>1.2$-fold $(P<0.05)$ stimulation of either human or ovine OSE cells that did not appear to be related to concentration. Treatment of OSE cells with HGF demonstrated that whereas ovine OSE cell growth was maximally stimulated 1.5 -fold $(P<0.05)$ in the presence of $100 \mathrm{ng} / \mathrm{ml} \mathrm{HGF}$, no significant response to HGF was observed in human OSE cells.

\section{Effect of gonadotropins on ovine and human OSE cell growth}

To measure the effect of gonadotropins on OSE cell growth, recombinant $\mathrm{FSH}, \mathrm{LH}$ and purified hCG were added to OSE cells (Fig. 4). Addition of FSH induced both human and ovine OSE cell growth, exhibiting $>1.2$-fold $(P<0.05)$ stimulation that was not related to concentration. Addition of LH or hCG similarly induced OSE cell growth; however, the cell-growth response appeared more

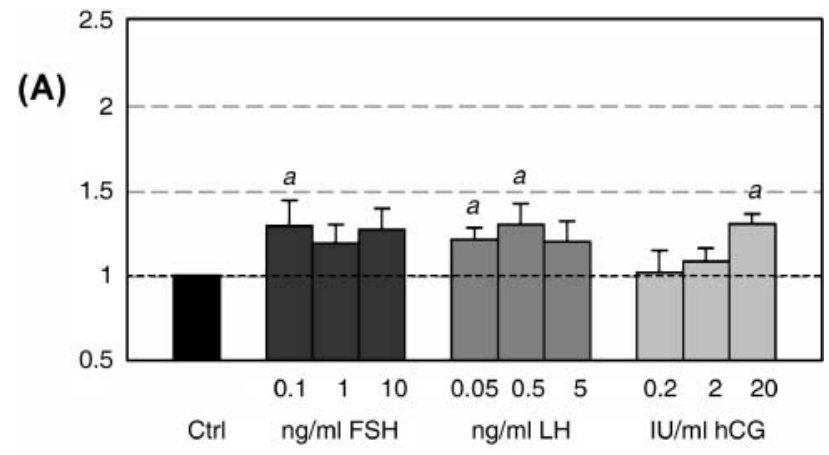

(B)

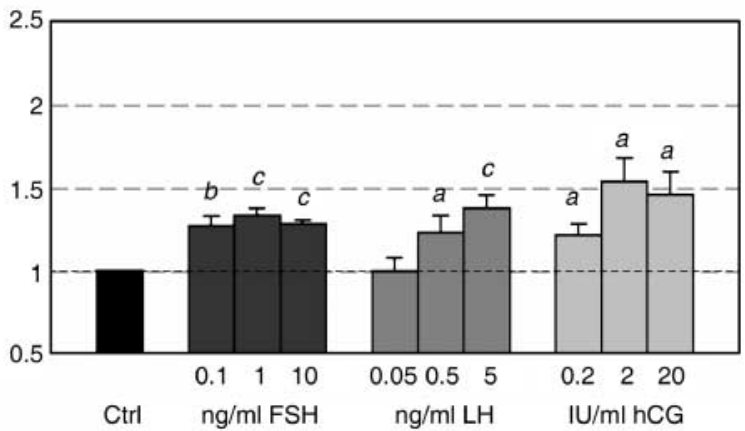

Figure 4 Effect of gonadotropins on (A) human and (B) ovine OSE cell growth. OSE cells were serum starved overnight and treated as indicated for 5 days. Cell number was ascertained using a tetrazoliumbased assay. Data $(n=6)$ were standardized to the control $(\mathrm{Ctrl})$ and are presented as fold increase and means \pm S.E.M. (a denotes $P<0.05, b$ denotes $P<0.01$ and $c$ denotes $P<0.001$ ). 
dose-responsive, exhibiting maximal 1.3 -fold $(P<0.05)$ stimulation with $0.5 \mathrm{ng} / \mathrm{ml} \mathrm{LH}$ in human OSE cells and 1.4 -fold $(P<0.001)$ stimulation with $5 \mathrm{ng} / \mathrm{ml} \mathrm{LH}$ in ovine OSE cells. Addition of hCG induced growth of human and ovine OSE cells, exhibiting $>1.2$-fold $(P<0.05)$ stimulation in human OSE cells and 1.5 -fold $(P<0.05)$ in ovine OSE cells at a concentration of $20 \mathrm{IU} / \mathrm{ml}$ hCG.

\section{Effect of PD98059 on hCG, IGF-I and HGF-induced OSE cell growth}

To further characterize induction of human and ovine OSE cell growth, activation of the ERK/MAP kinase signalling pathway was investigated. In order to examine ERKinduced OSE cell growth, the effects of hCG, IGF-I and HGF were further examined in the presence of PD98059, a specific inhibitor of MEK (Alessi et al. 1995; Fig. 5). When either human or ovine OSE cells were treated with hCG or IGF-I, no significant stimulation of cell growth was observed in the presence of PD98059 inhibitor. Similarly in ovine OSE cells, no significant stimulation of cell growth was observed in response to HGF in the presence of PD98059. The stimulation of human and ovine OSE cell growth in response to either hCG or IGF-I and ovine cell growth in response to HGF is therefore dependent on the MEK/ERK/MAP kinase pathway.

(A)

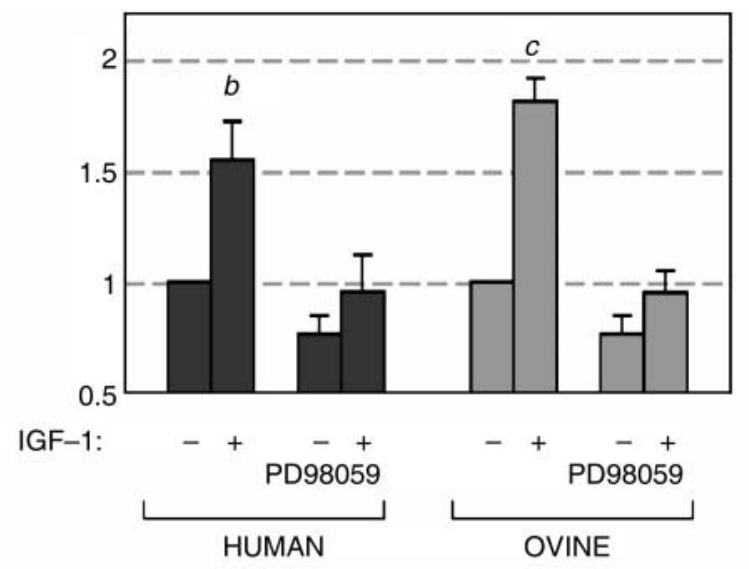

\section{Effect of hCG, IGF-I and HGF on ERK activation in human and ovine OSE cells}

In order to observe ERK activation in response to hCG, IGF-I or HGF, human and ovine OSE cells were treated with $20 \mathrm{IU} / \mathrm{ml}$ hCG, $100 \mathrm{ng} / \mathrm{ml}$ IGF-I or $50 \mathrm{ng} / \mathrm{ml} \mathrm{HGF}$ for 0,10 and $20 \mathrm{~min}$ and cell lysates subsequently analysed by Western blotting using antibodies against phosphorylated (Thr-202/Tyr-204) and native ERK (both ERK antibodies react with the ERK isoforms ERK 1 and ERK 2; see Fig. 6). For both human and ovine OSE cells, phosphorylation of ERK was stimulated in response to treatment with either IGF-I or hCG. In response to HGF, however, although phosphorylation of ERK was clearly observed in ovine OSE cells, ERK phosphorylation was barely detectable in human OSE cells.

\section{Discussion}

In order to establish ovine OSE cells as a suitable model for the study of human OSE cells, we have attempted to mimic post-ovulatory stages associated with the recovery of OSE cells in vivo by analysing the induction of antiinflammatory and proliferative responses in vitro. We show that an anti-inflammatory response, as evidenced by the IL-1 $\alpha$-induced increase of $11 \beta \mathrm{HSD}-1$ mRNA and oxoreductase activity, and responses to proliferative stimulation, are similar in both human and ovine OSE cells.

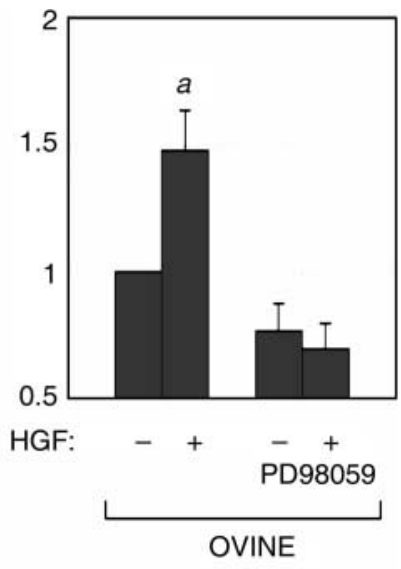

(B)

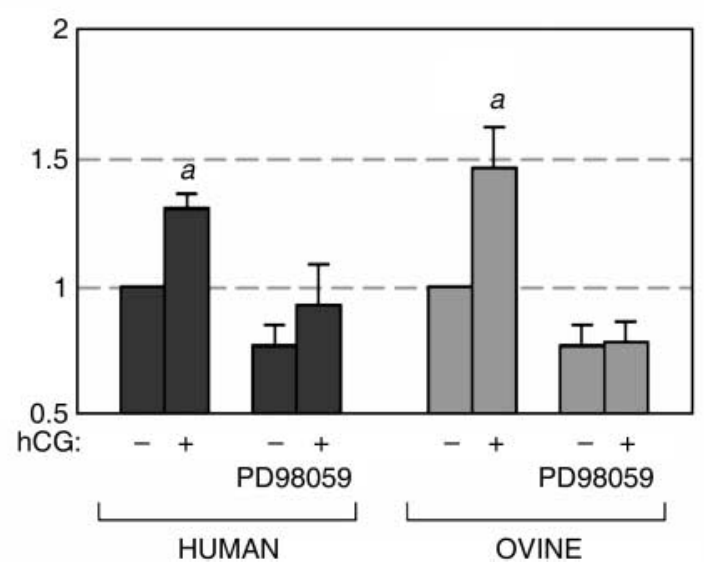

Figure 5 Effect of the inhibitor PD98059 on OSE cell growth induced by IGF-I $(100 \mathrm{ng} / \mathrm{ml})$ and HGF ( $50 \mathrm{ng} / \mathrm{ml}$; A) and OSE cell growth induced by hCG $(20 \mathrm{IU} / \mathrm{ml}$; B). OSE cells were serum starved overnight, incubated with PD98059 and treated as indicated for 3 days. Cell number was ascertained using a tetrazolium-based assay. Data $(n=6)$ were standardized to controls and are presented as fold increase and means \pm S.E.M. (a denotes $P<0.05, b$ denotes $P<0.01$ and $c$ denotes $P<0.001$ ). 
(A)
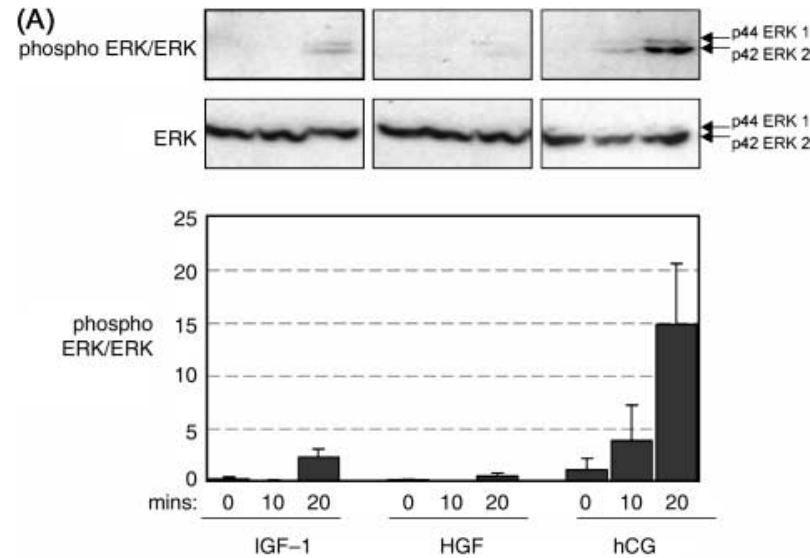

(B)
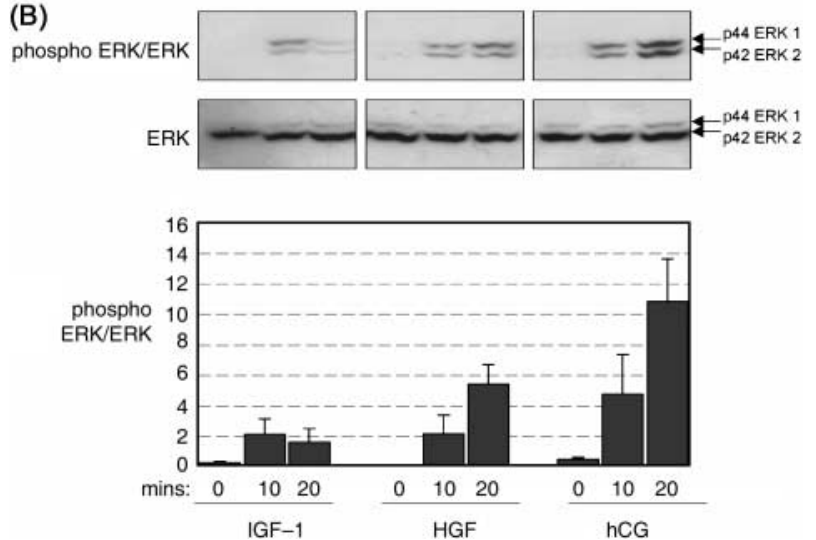

Figure 6 Effect of IGF-I, HGF and hCG on ERK phosphorylation in (A) human and (B) ovine OSE cells. OSE cells were serum starved overnight and treated with $100 \mathrm{ng} / \mathrm{ml} \mathrm{IGF-I,} 50 \mathrm{ng} / \mathrm{ml} \mathrm{HGF}$ or $20 \mathrm{IU} / \mathrm{ml}$ hCG for the times indicated. Western blotting was performed using antibodies against phosphorylated ERK or non-phosphorylated ERK, as indicated. One example of three experiments is presented. Bands from all experiments were quantified and are represented as phosphorylated ERK 1 and 2/total ERK 1 and 2 (as arbitrary units).

The observed increase of $11 \beta \mathrm{HSD}-1$ mRNA and oxoreductase activity in OSE cells treated with IL- $1 \alpha$ is believed to contribute to an anti-inflammatory environment at ovulation by increasing levels of cortisol. In preparation for ovulation, gonadotropins initiate an inflammatory response by causing local production of inflammatory mediators such as IL-1 $\alpha$ (Tetsuka et al. 1999). In the OSE cell layer, IL-1 $\alpha$ induces the prostaglandin pathway (Morris and Richards 1995, Hellberg et al. 1996, Rae et al. 2004) and the increased production of prostaglandin $E_{2}$ is sufficient to initiate ovulation (Smith and Langenbach 2001) causing collagen breakdown, apoptotic cell death and follicular rupture (Murdoch et al. 1999). The production of cortisol, caused by up-regulation of $11 \beta \mathrm{HSD}-1$, is therefore envisaged to counteract the inflammatory response. This is supported by recent evidence demonstrating that cortisol suppresses the level of cyclooxygenase-2 mRNA induced by IL-1 $\alpha$ (Rae et al. 2004). In addition to inducing inflammation, IL- $1 \alpha$ therefore also suppresses inflammation by increasing the level of cortisol.
The observed proliferative effects of gonadotropins, FSH, LH and hCG, support previous reports that indicate gonadotropin stimulation of human OSE cell growth in vitro (Kuroda et al. 2001, Syed et al. 2001, Choi et al. 2001). Using primary cultures of ovine OSE cells, similar mitogenic effects were also observed in response to gonadotropins. When the effect of growth factors was measured on both human and ovine OSE cell growth, IGFI and CTGF were shown to induce growth of human and ovine OSE cells similarly. The induction of either human or ovine OSE cell growth by IGF-I or hCG was further shown to be dependent on the MEK/ERK signalling pathway as demonstrated by inhibition of cell proliferation by PD98059 and induction of ERK 1/2 phosphorylation. For ovine OSE cells, HGF was similarly shown to induce cell growth via the ERK pathway; however, growth of human OSE cells was not significantly stimulated in response to HGF. The observation that ERK phosphorylation was clearly induced in response to HGF in ovine OSE cells, but barely detectable in response to HGF in human OSE cells, is consistent with the observed growth stimulation of ovine but not human OSE cell growth in response to HGF. Wong et al. (2001) demonstrated previously that HGF induces human OSE cell growth via the ERK pathway; however, it was also noted that the expression of the HGF receptor, c-met, is reduced with time of culture. Thus, although it is possible to observe a low response to HGF in our human OSE cell cultures at the level of ERK phosphorylation (Fig. 3), the level of c-met may be insufficiently high to observe any effect on cellular growth.

Our observation that the ERK/MAP kinase pathway is important for the induction of OSE cell growth is supported by previous studies using the MEK inhibitor PD98059 (Bilderback et al. 2002). The data presented here is also consistent with a previous report demonstrating the role of ERK in HGF-induced human OSE cell growth (Wong et al. 2001) and further demonstrates that IGF-I and hCG also induce OSE cell growth via the ERK pathway. Other signalling pathways that are important to maintain OSE cell growth and/or survival include the Akt/ phosphoinositide 3-kinase pathway (Bilderback et al. 2002); stimulation of the Akt/phosphoinositide 3-kinase pathway by IGF-I, under the control of hCG, induces cell survival (Kuroda et al. 2001).

In summary, we demonstrate that human and ovine OSE cell cultures respond similarly to the addition of the inflammatory cytokine IL- $1 \alpha$, as evidenced by an increase of $11 \beta \mathrm{HSD}-1$ mRNA and oxoreductase activity. Furthermore, proliferative responses to gonadotropins and growth factors are similar in human and ovine OSE cells and, at least for IGF-I and hCG, shown to be dependent on the ERK/MAP kinase signalling pathway. We conclude that human and ovine OSE cells share similarities associated with suppression of inflammation and induction of cellular growth that make the sheep a suitable model for the study of human OSE cells in vitro. 


\section{Acknowledgements}

This research was supported by Medical Research Council Programme grant number 0000066 and the European Commission EU contract EUK1-CT-2002-00128 (EURISKED).

\section{References}

Alessi DR, Cuenda A, Cohen P, Dudley DT \& Saltiel AR 1995 PD98059P is a specific inhibitor of the activation of mitogen-activated protein kinase kinase in vitro and in vivo. Journal of Biological Chemistry $27027489-27494$.

Andersen CY \& Hornnes P 1994 Intrafollicular concentrations of free cortisol close to follicular rupture. Human Reproduction $\mathbf{9}$ 1944-1949.

Auersperg N, Wong AS, Choi KC, Kang SK \& Leung PC 2001 Ovarian surface epithelium: biology, endocrinology, and pathology. Endocrine Reviews 22 255-288.

Bilderback TR, Lee F, Auersperg N \& Rodland KD 2002 3-kinase-dependent, MEK- independent proliferation in response to $\mathrm{CaR}$ activation. American Journal of Physiology. Cell Physiology 283 C282-C288.

Cai TQ, Wong B, Mundt SS, Thieringer R, Wright SD \& Hermanowski-Vosatka A 2001 Induction of 11 beta-hydroxysteroid dehydrogenase type 1 but not -2 in human aortic smooth muscle cells by inflammatory stimuli. Journal of Steroid Biochemistry and Molecular Biology 77 117-122.

Campbell BK, Souza C, Gong J, Webb R, Kendall N, Marsters P, Robinson G, Mitchell A, Telfer EE \& Baird DT 2003 Domestic ruminants as models for the elucidation of the mechanisms controlling ovarian follicle development in humans. Reproduction Supplement 61 429-443.

Choi KC, Kang SK, Tai CJ, Auersperg N \& Leung PC 2001 Estradiol up-regulates antiapoptotic $\mathrm{BCl}-2$ messenger ribonucleic acid and protein in tumorigenic ovarian surface epithelium cells. Endocrinology $1422351-2360$.

Escher G, Galli I, Vishwanath BS, Frey BM \& Frey FJ 1997 Tumor necrosis factor alpha and interleukin 1beta enhance the cortisone/ cortisol shuttle. Journal of Experimental Medicine 186 189-198.

Espey LL 1980 Ovulation as an inflammatory reaction-a hypothesis. Biology of Reproduction 22 73-106.

Espey LL 1994 Current status of the hypothesis that mammalian ovulation is comparable to an inflammatory reaction. Biology of Reproduction 50 233-238.

Feinstein MB \& Schleimer RP 1999 Regulation of the action of hydrocortisone in airway epithelial cells by 11 beta-hydroxysteroid dehydrogenase. American Journal of Respiratory Cell and Molecular Biology 21 403-408.

Hellberg P, Larson L, Olofsson J, Brannstrom M \& Hedin L 1996 Regulation of the inducible form of prostaglandin endoperoxide synthase in the perfused rat. Molecular Human Reproduction 2 111-116.

Hillier SG \& Tetsuka M 1998 An anti-inflammatory role for glucocorticoids in the ovaries? Journal of Reproductive Immunology 39 $21-27$.

Kuroda H, Mandai M, Konishi I, Tsuruta Y, Kusakari T, Kariya M \& Fujii S 2001 Human ovarian surface epithelial (OSE) cells express LH/hCG receptors, and hCG inhibits apoptosis of OSE cells via upregulation of insulin-like growth factor-1. International Journal of Cancer 91 309-315.

Leeuwenberg BR, Hudson NL, Moore LG, Hurst PR \& McNatty KP 1996 Peripheral and ovarian IGF-I concentrations during the ovine oestrous cycle. Journal of Endocrinology 148 281-289.

Liu J, Kosma VM, Vanttinen T, Hyden-Granskog C \& Voutilainen R 2002 Gonadotrophins inhibit the expression of insulin-like growth factor binding protein-related protein-2 mRNA in cultured human granulosa-luteal cells. Molecular Human Reproduction 8 136-141.

Morris JK \& Richards JS 1995 Luteinizing hormone induces prostaglandin endoperoxide synthase- 2 and luteinization in vitro by A-kinase and C-kinase pathways. Endocrinology 136 1549-1558.
Murdoch WJ \& McDonnel AC 2002 Roles of the ovarian surface epithelium in ovulation and carcinogenesis. Reproduction 123 $743-750$

Murdoch WJ, Wilken C \& Young DA 1999 Sequence of apoptosis and inflammatory necrosis within the formative ovulatory site of sheep follicles. Journal of Reproduction and Fertility 117 325-329.

Ness RB, Grisso JA, Cottreau C, Klapper J, Vergona R, Wheeler JE, Morgan M \& Schlesselman JJ 2000 Factors related to inflammation of the ovarian epithelium and risk of ovarian cancer. Epidemiology 11 111-117.

Parrott JA, Doraiswamy V, Kim G, Mosher R \& Skinner MK 2001 Expression and actions of both the follicle stimulating hormone receptor and the luteinizing hormone receptor in normal ovarian surface epithelium and ovarian cancer. Molecular and Cellular Endocrinology 172 213-222.

Piver MS, Baker TR, Piedmonte M \& Sandecki AM 1991 Epidemiology and etiology of ovarian cancer. Seminars in Oncology 18 177-185.

Rae MT, Niven D, Critchley HOD, Harlow CR \& Hillier SG 2004 Antiinflammatory steroid action in human ovarian surface epithelial cells. Journal of Clinical Endocrinology and Metabolism (In Press).

Richardson GS, Scully RE, Nikrui N \& Nelson JH Jr 1985 Common epithelial cancer of the ovary (2). New England Journal of Medicine 312 474-483 and 415-424.

Schleimer RP 1991 Potential regulation of inflammation in the lung by local metabolism of hydrocortisone. American Journal of Respiratory Cell and Molecular Biology 4 166-173.

Slee RB, Hillier SG, Largue P, Harlow CR, Miele G \& Clinton M 2001 Differentiation-dependent expression of connective tissue growth factor and lysyl oxidase messenger ribonucleic acids in rat granulosa cells. Endocrinology 142 1082-1089.

Smith WL \& Langenbach R 2001 Why there are two cyclooxygenase isozymes. Journal of Clinical Investigation 107 1491-1495.

Stewart PM \& Mason JI 1995 Cortisol to cortisone: glucocorticoid to mineralocorticoid. Steroids $60143-146$.

Syed V, Ulinski G, Mok SC, Yiu GK \& Ho SM 2001 Expression of gonadotropin receptor and growth responses to key reproductive hormones in normal and malignant human ovarian surface epithelial cells. Cancer Research 61 6768-6776.

Tannin GM, Agarwal AK, Monder C, New MI \& White PC 1991 The human gene for 11 beta-hydroxysteroid dehydrogenase. Structure, tissue distribution, and chromosomal localisation. Journal of Biological Chemistry 266 16653-16658.

Tetsuka M, Haines LC, Milne M, Simpson GE \& Hillier SG 1999 Regulation of 11 beta-hydroxysteroid dehydrogenase type 1 gene expression by $\mathrm{LH}$ and interleukin-1beta in cultured rat granulosa cells. Journal of Endocrinology 163 417-423.

Thomas FJ, Thomas MJ, Tetsuka M, Mason JI \& Hillier SG 1998 Corticosteroid metabolism in human granulosa-lutein cells. Clinical Endocrinology 48 509-513.

Wong AS, Pelech SL, Woo MM, Yim G, Rosen B, Ehlen T, Leung PC \& Auersperg N 2001 Coexpression of hepatocyte growth factor-Met: an early step in ovarian carcinogenesis? Oncogene 20 1318-1328.

Yong PY, Harlow C, Thong KJ \& Hillier SG 2002 Regulation of 11 beta-hydroxysteroid dehydrogenase type 1 gene expression in human ovarian surface epithelial cells by interleukin-1. Human Reproduction 17 2300-2306; Erratum in Human Reproduction 2002173009.

Zachow RJ \& Woolery JK 2002 Effects of hepatocyte growth factor on cyclic nucleotide-dependent signaling and steroidogenesis in rat ovarian granulosa cells in vitro. Biology of Reproduction 67 $454-459$

Received 7 April 2004

First decision 3 June 2004

Revised manuscript received 7 July 2004

Accepted 19 July 2004 